\title{
UNDERSTANDING HOUSEHOLD'S TRAVEL COSTS BUDGET FRONTIER IN BANDA ACEH, INDONESIA
}

\author{
Sugiarto Sugiarto $^{1 \text {,* }}$, Lulusi ${ }^{1}$, Muhammad Isya ${ }^{1}$, Fadhlullah Apriandy ${ }^{1}$, Fuadh Ramadhan ${ }^{2}$ \\ ${ }^{1}$ Department of Civil Engineering, Universitas Syiah Kuala, Banda Aceh, Indonesia \\ ${ }^{2}$ Alumni, Department of Civil Engineering, Universitas Syiah Kuala, Banda Aceh, Indonesia \\ *E-mail of corresponding author: sugiarto@unsyiah.ac.id
}

\section{Resume}

This study aims to explore the constraints of the Travel Costs Budget Frontier (TCBF) before a full-charged fare is implemented for the bus system known as the "Trans Koetaradja" in the city of Banda Aceh, Indonesia. A stochastic frontier analysis was used to identify how people allocate their share of income for transportation in line with their mobility and socio-demographic characteristics. The findings showed the TCBF to be influenced by commuting trip activities, private mode usage, owning car and motorcycle and income limits. Barriers were observed to be restricting the low-medium income groups. Owning their own private modes within the low-medium income groups does mean household disbursement and could impose their transport expenditure rather than public modes usage. There is a need to devise policies considering the low-medium incomes to implement impartial full-charge to ensure affordable bus fare.

Available online: https://doi.org/10.26552/com.C.2021.2.A116-A124

\section{Article info}

Received 13 August 2020

Accepted 21 October 2020

Online 4 March 2021

\section{Keywords:}

travel costs,

budget,

frontier,

stochastic frontier,

urban bus,

Indonesia

\section{Introduction}

Rapid motorization, promising economic growth and the aftermath of rapid urbanization have increased the time and money spent by people on daily travels and this has further affected their expenditure significantly. In modern society, other factors with a substantial effect on travel costs expenditure include changes in technology, incomes, attitudes, social demographics, and travel behaviors [1].

The use of personal mobility in Indonesia, including Banda Aceh, causes certain transport-related problems such as increased travel time, fuel consumption and environmental deterioration [2-3]. This has, however, driven government and transport planners to alleviate high dependence on the private mode by encouraging changes in the travel mode. Therefore, public transport such as the bus system is commonly recognized as the valid transport policy to reduce the use of the private mode of transportation. Moreover, a public transport system has recognized as a low-carbon transport strategy and a vital for sustainable urban development. However, introducing such a system in emerging cities could be a challenge as people are usually traveling using private vehicles [4]. To encourage changes in the travel mode previous studies have paid much intention to working on travel behavior adoption and forecast the demand for bus usage by incommoding travel behavior adaptation. For instance, research by [5] has concluded that improving attitudes towards the physical activity can increase bus use and reduce physical inactivity, partly caused by car dependence. Furthermore, an examination of the potential effect of attitudes towards physical activity on the bus utility in the context of a rural Japan, studied by authors of [6], has shown that the level and opportunity for physical activity are generally low. In terms of the public transport demand forecasting, forecasting the demand for new public transportation is essential for appropriate policymaking. The effects of social interactions on individual choices are attracting considerable attention and these interactions have been evaluated in the relationship between the individual's behavior and the group's behavior [7].

Particularly in Banda Aceh, several earliest studies have investigated the effect of motorcycles usage on commuting patterns [8] and approval of the public for adoption of bus reform proposed by the Government in 2016 [9]. This works conluded that it is necessary to consider the motorcycle commuting patterns due to the significant influence of motorcyclists on commuting trips [10], thereby, leading to implementation of a bus reform known as the "Trans Koetaradja" by the government which is currently being run as a trial, free of charge, within running corridors with the full charge for the services expected to start by 2020 [3, 9]. Furthermore, regarding the free of charge during a trial run, the government has operated the Trans Koetardja bus in order to mitigate highly private mode dependency. As the initial stage, since the bus reform introduced and implemented by the year 2016, the subsidy for the free fare for all the bus users is applied by the government as the 


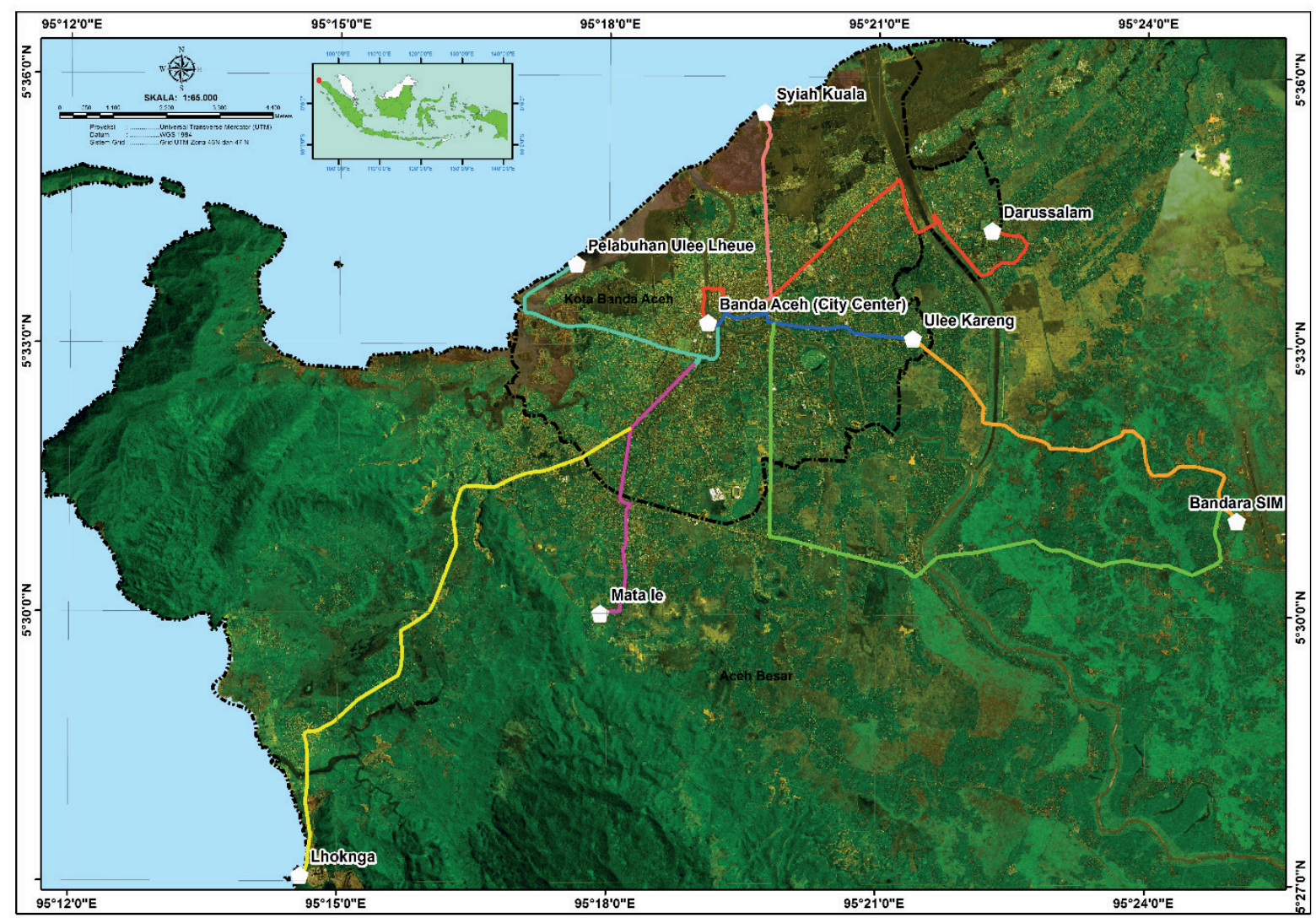

Figure 1 Banda Aceh city and Trans Koetaradja Lines

incentive for private mode users in order to shift from their own car and motorcycle to the bus. By the year 2020, the government has planned and has under consideration to maintain the subsidy only for low-income households and students.

Implementation of the full charge is exceptionally problematic especially for primarily low-income commuters requiring adequate access to public transport as necessary municipal facilities due to the monetary expenditures it is expected to impose on them. It is also presumed that certain income groups save the travel costs expenditure due to income constraints. This means there is a need to understand the money expended on traveling and other factors necessary to determine travelers' behavior before implementing a full fare for the bus system. This study was, therefore, conducted to explore travel costs frontier constraints before the implementation of a full-charged tariff for the urban bus system in the city of Banda Aceh.

Stochastic production frontier was used in this study considering the aggregation of household income groups, including the low-medium and high monthly income groups. According to [1], Travel Costs Budget Frontier (TCBF) is defined as a maximum or unobserved capacity amount of money a specific income group is willing to allocate for travel routines. Therefore, the observed household travel costs in a month was treated as an exogenous variable using the data collected in six districts of Banda Aceh in late 2018, as indicated in Figure 1. The remaining part of this article is categorized into several sections to describe the survey and data profiles, model formulation and estimation after which the discussion and conclusions are presented at the end.

\section{Area of study}

Household transport survey (HTS) was conducted on householders in six districts of Banda Aceh including Ulee Kareng, Lueng Bata, Kuta Radja, Meuraxa, Syiah Kuala and Kuta Alam, as illustrated in Figure 2. This was a paperpencil-based direct interview in late 2018 with a total of 400 valid questionnaires collected and used in the preliminary analysis, with the summary provided in Table 1 consisting of the time of the survey, target area, distribution method, number of valid samples and outline. The focus was to collect information related to travel and social-economic attributes.

\section{Method and data distribution}

The questionnaires were designed to capture relevant information on travel behavior and socio-demographic attributes from targeted respondents using the paper-pencilbased direct interviews based on Stated Preference choices [3, 9, 11-12] to design questionnaires for 400 samples.

The modeling approach of Stochastic Frontier Analysis (SFA) introduced initially by [13] and widely applied to travel 


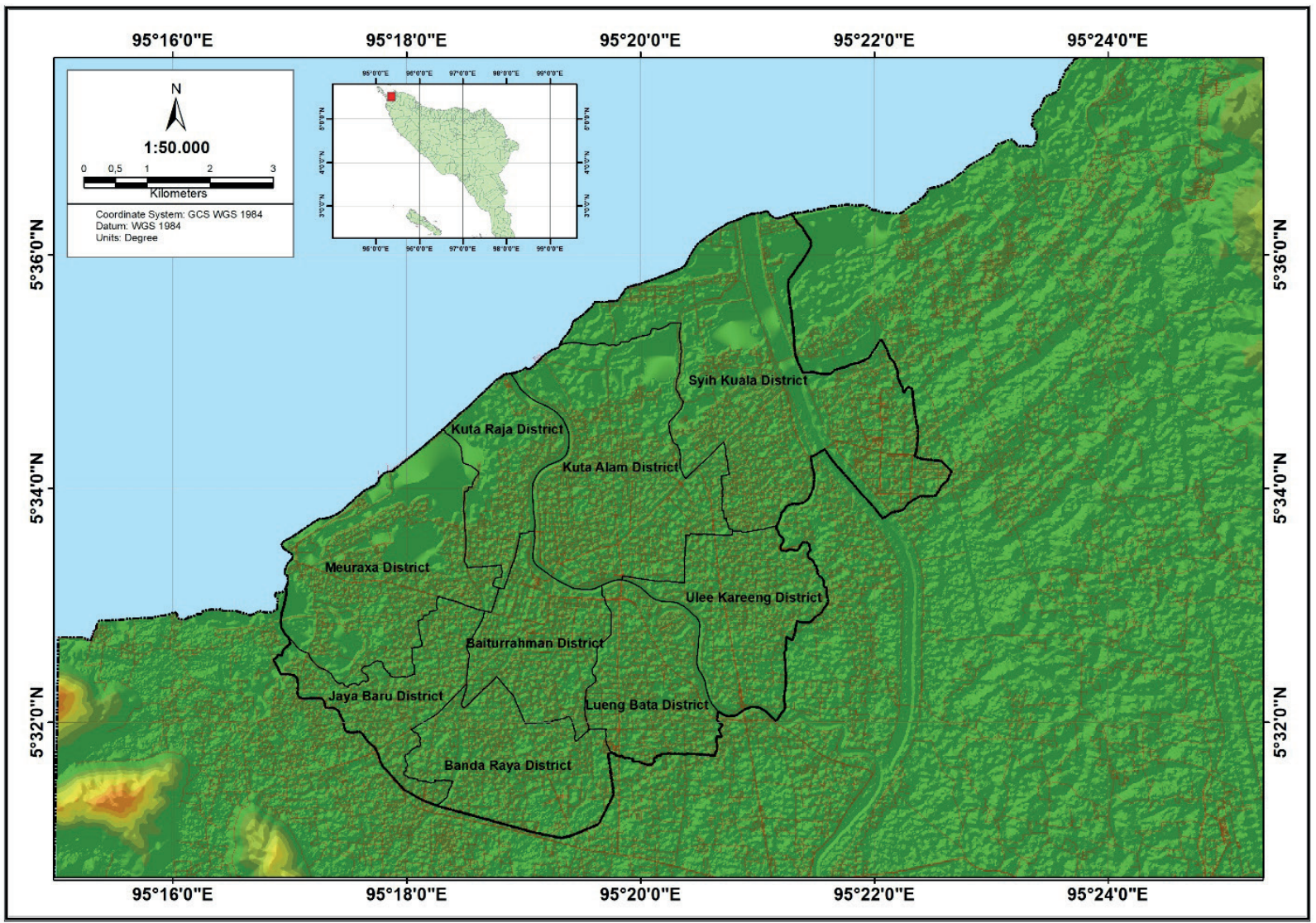

Figure 2 Banda Aceh city and its district areas

Table 1 Summary of SP questionnaire

\begin{tabular}{ll}
\hline description & detail \\
\hline time of survey & November 2018 \\
target location & Banda Aceh, Aceh province \\
distribution methods & a paper-pencil based direct interviews and collected by the enumerator \\
number of questionnaires valid & 400 samples \\
questionnaire outline: & mode use, the purpose of traveling, origin zone, destination zone, travel distance, \\
part 1: travel attributes & travel time, frequency use of representative mode \\
part 2: social-economic attributes & monthly income, monthly travel expenditure, gender, age, education level, \\
& occupancy, housing owned status, household member, number of household \\
& work, car ownership, motorcycle ownership \\
\hline
\end{tabular}

time expenditures was adopted in this study. Moreover, household attributes have been used by [14] to explore the travel time expenditure across the United States, India and Switzerland and found quite different values in the average travel time frontier across the international contexts. Another research by [15] investigated unseen stochastic limit and variations of individual travel time using data set from the UK National Travel Survey.

Further application of the SFA on the travel time expenditure frontier done by [16], they investigated and showed differences in the frontier values and trends in the ratio of travel time expenditure to frontier values differ considerably across socio-demographic groups in the United States. However, the travel costs expenditures were considered a more crucial issue due to their direct burden on income constraints compared to travel time expenditure. Perhaps, the earliest studies on the travel costs expenditure or transportation expenditure have been conducted by $[1,17]$. They utilized the SFA to estimate unobserved travel costs frontier or capacity within the targeted household. They explored how the household spends the money on transportation, as well as how life stages and related household attributes contributed to transportation fee expenditures in the Jakarta Metropolitan Area. The substantial characteristics of household attributes among life stage categories are taken into consideration. They concluded that a larger amount of the travel costs expenditure is found for a single-person and families only with adults and the transportation expenditure in Jakarta is influenced by household attributes and life environments. 
Table 2 Distribution of Socio-demographic attributes

\begin{tabular}{|c|c|c|c|}
\hline item & category & number of samples & share (\%) \\
\hline \multirow[t]{2}{*}{ gender } & male & 331 & 83 \\
\hline & female & 69 & 17 \\
\hline \multirow[t]{6}{*}{ age } & 19 years or less & 2 & 1 \\
\hline & 20 - 29 years & 58 & 15 \\
\hline & 30 - 39 years & 125 & 31 \\
\hline & 40 - 49 years & 127 & 32 \\
\hline & 50 - 59 years & 79 & 19 \\
\hline & 60 years or more & 9 & 2 \\
\hline \multirow[t]{4}{*}{ education } & primary school & 219 & 55 \\
\hline & college & 53 & 13 \\
\hline & university/bachelor & 91 & 23 \\
\hline & university/postgraduate & 37 & 9 \\
\hline \multirow[t]{4}{*}{ monthly income } & 1.9 million IDR (135.62 USD) or less & 71 & 18 \\
\hline & 2 - 4.9 million IDR (142.76-349.77 USD) & 197 & 49 \\
\hline & 5 - 6.9 million IDR (356.90-492.53 USD) & 90 & 23 \\
\hline & 7 million IDR (499.66) or more & 42 & 11 \\
\hline \multirow[t]{5}{*}{ monthly travel costs } & 0.19 million IDR (13.56 USD) or less & 54 & 14 \\
\hline & 0.2-0.99 million IDR (14.28-64.24 USD) & 128 & 32 \\
\hline & 1-1.49 million IDR (71.38-106.36 USD) & 164 & 41 \\
\hline & 1.5-1.99 million IDR (107.07-135.62 USD) & 38 & 10 \\
\hline & 2 million IDR (142.76 USD) or more & 16 & 4 \\
\hline \multirow[t]{4}{*}{ occupation } & working & 318 & 80 \\
\hline & university student & 30 & 8 \\
\hline & housewife & 23 & 6 \\
\hline & part-time worker & 29 & 7 \\
\hline \multirow[t]{2}{*}{ housing own status } & owned & 363 & 92 \\
\hline & renting & 31 & 8 \\
\hline
\end{tabular}

Further exploration of the travel costs budget is conducted by authors of [11], which have investigated factors affecting household travel costs budget in Banda Aceh considering household life stages and applying only for bus usages. This investigation is the first stage of the same funding with this work. The differences between this work and work done by [11] are in the targeted respondents and group of households. This work focuses on how people in Banda Aceh spent their monthly transportation expenditure considering income group segmentations, while the previous work [11] is more specific investigating the bus usage, using an onboard survey and has targeted groups based on household life stages. The modeling framework used for both exploring travel time and travel costs frontier is based on the SFA or also known as the Stochastic Frontier Model (SFM).

The SFA is used to estimate unobserved travel costs frontier or capacity within the targeted household and it was found to be always greater than or equal to the observed travel costs expenditure. Therefore, the modeling of travel costs budget frontier (TCBF) was based on inequality and non-negative term or production function. A log transformation of travel costs budget (TCB) was also used to ensure positive prediction due to the highly skewed nature dataset of TCB distribution [1].

Let $T_{i}=\ln \left(t_{i}\right)$, and $T_{i}=t_{i}-u_{i}$,

where $i$ denotes the observation, $t_{i}$ is observed transportation expenditure and $u_{i}$ is a random component with non-negative values. Moreover, $\tau_{i}$ represents an unobserved frontier for $T_{i}$ and found to be always greater than or equal to $T_{i}$ and this means that it is possible to write the production function of TCBF as:

$\tau_{i}=\beta^{\prime} X_{i}+v_{i}$

then,

$T_{i}=\beta^{\prime} X_{i}+\varepsilon_{i}=\beta^{\prime} X_{i}+v_{i}-u_{i}$, 
Table 3 Summary of Respondent's Mobility Attributes

\begin{tabular}{|c|c|c|c|}
\hline item & category & number of samples & share $(\%)$ \\
\hline \multirow[t]{3}{*}{ travel mode choice } & car & 125 & 31 \\
\hline & motorcycle & 207 & 52 \\
\hline & public transport (bus) & 68 & 17 \\
\hline \multirow[t]{3}{*}{ driver's license } & has driver's license & 342 & 86 \\
\hline & has no driver's & 58 & 14 \\
\hline & license & & \\
\hline \multirow[t]{2}{*}{ car owned within household } & has owned car & 135 & 34 \\
\hline & has no owned car & 265 & 66 \\
\hline \multirow[t]{2}{*}{ motorcycle owned within household } & has owned motorcycle & 376 & 94 \\
\hline & has no owned motorcycle & 24 & 6 \\
\hline
\end{tabular}

where $\beta^{\prime}$ is a coefficient vector of independent variables, $X_{i}$ is a vector of explanatory variables, $v_{i}$ is a random error term such that $-\infty<v_{i}<\infty$. The random variable of $v_{i}$ is typically assumed to be normally identical and independent distributed IID as $\mathrm{N}\left(0, \sigma v^{2}\right)$ while a half normal or truncated-normal distribution is commonly used for the error component of $u_{i}$. Moreover, the ratio $(R)$ value was considered to gain more information on how households spend their travel costs capacity or frontier. The amount of $\mathrm{R}$ was calculated as:

$R=\frac{E\left(t_{i}\right)}{E\left(T C B F_{i}\right)}=E\left[\exp \left(-u_{i}\right)\right]$

The ratio value implies that people are expected to spend $R$ time of (TCBF) of a certain group/household income as monthly expenditure. The $R$-value indicates the extent to which each household is spending in terms of frontiers and a large value shows they mostly use their frontiers and vice versa

The respondent's socio-demographic attributes were aggregated, as described in Table 2, before the estimation model and results showed that the male respondents were predominant compared to females with $83 \%$. The respondents were also slightly dominated by people between 30 to 50 years by having a total of $63 \%$, while more than half have education level up to primary school as indicate by $55 \%$. The findings also showed $80 \%$ were working while the remaining were university students, housewives and part-time workers. Moreover, approximately $92 \%$ have their own house while only $8 \%$ lived in a rented apartment and the monthly income attribute indicated $67 \%$ are categorized as low-medium with income below 5 million IDR [17]. The information also showed $73 \%$ spent 0.2 to 1.5 million IDR ( $1 \mathrm{USD} \cong 14.09$ thousand IDR) of their monthly income on travel.

Table 3 describes the aggregation results for respondent's mobility attributes during the distributed questionnaires. The aggregation of the data depicts that people in Banda Aceh have significantly private mode dependency accounting for $31 \%$ and $52 \%$ for car and motorcycle usage, respectively, while it shows that only a few of them (17\%) used public transport. It is quite clear that respondents prefer to use their own mode compared to public transit. Furthermore, the data reveal that close to $86 \%$ of respondents are licensed drivers. This result is quite consistent with the share of private mode choice as much as $83 \%$ among respondents has preferred to use their own mode. Moreover, the data reveal that a high percentage of respondents have owned a motorcycle (94\%) within a household compared to the owned car (34\%) within the household. Surprisingly, only a few of the household has no owned motorcycle (6\%) in this city. Therefore, it seems that people rely heavily on their own mode, which offers more convenience in terms of flexibility.

\section{Empirical setting and result}

The TCBF was calibrated for the two income groups which are the low-medium and high, while the observed travel costs in a month (in million rupiahs (IDR)) were treated as an exogenous variable. The setting and statistical characteristics, including the mean and standard deviation of both exogenous and endogenous variables used in this study, are presented in Table 4. It is important to note that the information in Table 2 shows 268 represented by $67 \%$ of the 400 households analyzed have the low-medium income at $<5$ million IDR per month while the remaining 132 families have the high income at $>5$ million IDR per month. The average income was, however, found to be approximately 3.228 million IDR per month.

Table 5 depicts the effect of calibrated parameters on the travel costs frontier across the household income groups and the sign (-) represents explanatory variables with insignificant t-statistics. The endogenous variables varied among the two groups were distance, travel time, frequency of using the private mode, household income and household members. The findings, however, showed that the household income, private mode ownership including car and motorcycle and individual mode dummy variables have a positive impact on travel costs frontier for lowincome groups. This is associated with their limited income, which makes owning and using private modes to have a significant impact on their daily transport expenditure; 
Table 4 Variables' setting and statistical characteristics

\begin{tabular}{|c|c|c|c|c|}
\hline \multirow{2}{*}{ variable setting } & \multicolumn{2}{|c|}{ low-medium income group } & \multicolumn{2}{|c|}{ high-income group } \\
\hline & mean & std. dev & mean & std. dev \\
\hline travel costs (million IDR), numerical & 0.856 & 0.356 & 1.575 & 0.351 \\
\hline private mode user dummy 1 , otherwise 0 & 0.668 & 0.472 & 0.992 & 0.087 \\
\hline commuter trip dummy 1 , otherwise 0 & 0.806 & 0.396 & 0.962 & 0.191 \\
\hline distance $(\mathrm{km})$ & 3.287 & 2.226 & 4.821 & 2.236 \\
\hline travel time (minutes) & 9.174 & 5.359 & 13.024 & 5.396 \\
\hline frequency using private mode (number/week) & 5.074 & 1.310 & 5.636 & 1.086 \\
\hline household income (million IDR) & 2.690 & 0.552 & 6.318 & 0.467 \\
\hline male dummy 1 , otherwise 0 & 0.757 & 0.429 & 0.969 & 0.172 \\
\hline low education dummy 1 , otherwise 0 & 0.242 & 0.409 & 0.121 & 0.327 \\
\hline household member (number) & 1.459 & 0.549 & 2.295 & 0.576 \\
\hline car ownership (number) & 0.086 & 0.281 & 1.068 & 0.608 \\
\hline motorcycle ownership (number) & 1.407 & 0.661 & 2.227 & 0.613 \\
\hline sample size & \multicolumn{2}{|c|}{268} & \multicolumn{2}{|c|}{132} \\
\hline
\end{tabular}

Table 5 The TCF model calibrated parameters across income groups

\begin{tabular}{|c|c|c|c|c|}
\hline \multirow[t]{2}{*}{ variable } & \multicolumn{2}{|c|}{$\begin{array}{l}\text { low-medium } \\
\text { income group }\end{array}$} & \multicolumn{2}{|c|}{ high-income group } \\
\hline & coefficient & sig. & coefficient & sig. \\
\hline private mode user dummy 1 , otherwise 0 & 0.129 & 0.002 & - & - \\
\hline commuter trip dummy 1 , otherwise 0 & 0.212 & 0.002 & 0.331 & 0.000 \\
\hline distance $(\mathrm{km})$ & - & - & 0.0168 & 0.012 \\
\hline travel time (minutes) & 0.0126 & 0.001 & - & - \\
\hline frequency using private mode (number/week) & 0.020 & 0.028 & - & - \\
\hline household income (million IDR) & 0.129 & 0.002 & - & - \\
\hline male dummy 1 , otherwise 0 & - & - & 0.163 & 0.038 \\
\hline low education dummy 1 , otherwise 0 & - & - & -0.135 & 0.002 \\
\hline household member (number) & 0.198 & 0.000 & - & - \\
\hline car ownership (number) & 0.292 & 0.000 & 0.144 & 0.000 \\
\hline motorcycle ownership (number) & 0.173 & 0.000 & 0.0982 & 0.000 \\
\hline intercept (constant) & -1.294 & 0.000 & -0.344 & 0.005 \\
\hline number of observations (N) & \multicolumn{2}{|c|}{268} & \multicolumn{2}{|c|}{132} \\
\hline log-likelihood function (LL) & \multicolumn{2}{|c|}{-48.609} & \multicolumn{2}{|c|}{-59.029} \\
\hline wald $\chi 2$ (sig.) & \multicolumn{2}{|c|}{$221.09(0.000)$} & \multicolumn{2}{|c|}{$142.82(0.000)$} \\
\hline \multicolumn{5}{|l|}{ variance: } \\
\hline sigma-squared (v) & \multicolumn{2}{|c|}{0.442} & \multicolumn{2}{|c|}{0.178} \\
\hline sigma-squared (u) & \multicolumn{2}{|c|}{0.144} & \multicolumn{2}{|c|}{0.113} \\
\hline $\operatorname{lambda}(\lambda)$ & \multicolumn{2}{|c|}{3.059} & \multicolumn{2}{|c|}{1.573} \\
\hline$r(\exp (-u))$ & \multicolumn{2}{|c|}{0.642} & \multicolumn{2}{|c|}{0.837} \\
\hline
\end{tabular}

rather than use of a public mode. Meanwhile, the monthly income of the high-income group was found not to have any effect on the travel costs expenditure and this is assumed to be based on two reasons, which include having a buffer to their income capacity and spending most of their capacity on expenditures. The commuting trip variable was discovered to have a significant statistical sign across all the groups with both recorded to have the tendency to use their income resources for mandatory activities such as working and dropping/picking-up kids in and from schools.

The male gender was observed to have a significant positive influence on the travel costs frontier for a highincome household with the male respondents found to spend more on travel than their female counterparts and the same was also discovered with the commuter trips variable. This is possibly due to the fact that there are more males in high-income households as shown in Table 2. Furthermore, Table 5 represents how owning a car and motorcycle within a household could significantly be influencing the corresponding household in allocating transportation expenditure. It is implied that car and motorcycle ownership has a significantly positive 
correlation on the transportation expenditure frontier for both the low-income and high-income segmentation. The impact of owning private vehicles on the transport expenditure for the low-income groups seems to have a higher coefficient compared to the high-income one. This means that car and motorcycle ownership does means household disbursement in our dataset. That is, the private modes may possibly impose their monthly expenditure on transportation rather than bus usage. However, in this study, the exploration among specific income groups by considering the number of owning cars or motorcycles within a household has remained a future direction of this study.

The variance value of the half-normal random component (Sigma-squared $(\mathrm{u})$ ) was discovered to be substantially small for both income groups and this indicates that the observed travel costs across income groups is closer to the capacity or frontier. Moreover, the calibrated model parameters in Table 5 were found to be corresponding with income groups as observed with the tendency to be constrained by spending more income on commuting trips, private mode usage, owning private mode of transportation and based on the household members, as well as the limited income, which restricts certain group from spending on transportation. Furthermore, the $R$-value for the low-medium and high-income groups was recorded to be is 0.642 and 0.837 , respectively and this means that the high-income group actual costs expenditure is closer to their frontier values, while those in a low-medium group mostly use their frontier due to lack of buffer $[1,17]$.

\section{Conclusion}

The stochastic frontier analysis implemented in this study showed the frontier costs to be substantially influenced by commuting trip activities, private mode usage, owning car and motorcycle and constraints from monthly income. The finding further reported an average income groups considerably spending more than one-half of their maximum expenditure on transport routine while.
The ratio value indicated high-income group has the higher travel costs frontier compared to the low-medium groups. This difference is prospectively due to the limitation in the money attributable to travel mode, household members and owning car and motorcycle within income groups. Moreover, some barriers were observed to be restricting the low-medium income groups from spending money on transportation. The constraints may include their household's income limitation.

The empirical results further showed that the people in Banda Aceh save money for travel expenditure due to owning a car and motorcycle particularly for the lowmedium income groups. Car and motorcycle ownership within the low-medium income groups means household disbursement and may impose their monthly expenditure on transportation rather than public modes usage. This information is expected to provide an insight for policymakers while considering the monetary constraints in deciding the fare to charge for the bus system, as well as in determining the best policies to be implemented based on income groups, especially in relation to factors inhibiting them from commuting trips. Therefore, policies reflecting the needs of certain income groups need to be formulated to ensure impartiality during the implementation of the full-charge in the bus system and make it more affordable. It is also better to understand the travel behavior of residents to achieve successful and more efficient transport planning, particularly dealing with behavioral adopting the commuting trip in emerging cities [18-21].

\section{Acknowledgment}

The authors express their gratitude to the Universitas Syiah Kuala for providing financial support for this study under Contract No. 522/UN11/SPK/PNBP/2019. The authors also appreciate the staff and students of Transportation System Laboratory, Civil Engineering Department of Syiah Kuala University for providing substantial help with data collection. The authors also take responsibility for the remaining oversight in this study.

\section{References}

[1] SUGIARTO, S., MIWA, T., SATO, H., MORIKAWA, T. Transportation expenditure frontier models in Jakarta Metropolitan Area. Procedia-Social and Behavioral Sciences [online]. 2014, 138, p. 148-158. ISSN 1877-0428. Available from: https://doi.org/10.1016/j.sbspro.2014.07.190

[2] SUGIARTO, S., MIWA, T., SATO, H., MORIKAWA, T. Congestion charging: influence of public consciousness on acceptability in Jakarta Metropolitan Area. In: 21st World Congress on Intelligent Transport Systems: proceedings. Vol. 12914. 2014.

[3] SAlEH, S. M., SUGIARTO, S., SALMANNUR, A. Attitudinal dataset for mediating the effects of public acceptance on bus reform scheme in a developing country context. Data in Brief [online]. 2019, 25, 104035. ISSN 2352-3409. Available from: https://doi.org/10.1016/j.dib.2019.104035

[4] NGUYEN, T. N., MIWA, T., MORIKAWA, T. Response to the planned public transport system in Ho Chi Minh City: analysis of latent classes. Clean Technologies and Environmental Policy [online]. 2019, 21(10), p. 1925-1935. ISSN 1618-954X, eISSN 1618-9558. Available from: https://doi.org/10.1007/s10098-018-1638-8 
[5] TRAN, Y., YAMAMOTO, T., SATO, H., MIWA, T., MORIKAWA, T. Attitude toward physical activity as a determinant of bus use intention: a case study in Asuke, Japan. IATSS Research [online]. 2020, article in press. ISSN 0386-1112. Available from: https://doi.org/10.1016/j.iatssr.2020.03.002

[6] TRAN, Y., YAMAMOTO, T., SATO, H., MIWA, T., MORIKAWA, T. The analysis of influences of attitudes on mode choice under highly unbalanced mode share patterns. Journal of Choice Modelling [online]. 2020, 36, 100227. ISSN 1755-5345. Available from: https://doi.org/10.1016/j.jocm.2020.100227

[7] NGUYEN, T. N., MIWA, T., MORIKAWA, T. Demand forecast of public transportation considering positive and negative mass effects. Transportation Research Part D: Transport and Environment [online]. 2020, 85, 02466. ISSN 1361-9209. Available from: https://doi.org/10.1016/j.trd.2020.102466

[8] SALEH, S. M., SUGIARTO, S., HILAL, A,. ARIANSYAH, D. A Study on the traffic impact of the road corridors due to flyover construction at Surabaya Intersection, Banda Aceh of Indonesia. AIP Conference Proceedings [online]. 2017, 1903(1), 06005. ISSN 0094-243X, eISSN 1551-7616. Available from: https://doi.org/10.1063/1.5011559

[9] SALEH, S. M., SUGIARTO, S., ANGGRAINI, R. Analysis on public's response toward bus reform policy in Indonesia considering latent variables. The Open Transportation Journal [online]. 2019, 13, p. 17-24. ISSN 1874-4478, eISSN 2667-1212. Available from: http://dx.doi.org/10.2174/1874447801913010017

[10] AGGRAINI, R., SUGIARTO, S., PRAMANDA, H. Factors affecting trip generation of motorcyclist for the purpose of nonmandatory activities. AIP Conference Proceedings [online]. 2017, 1903(1), 060011. ISSN 0094-243X, eISSN 1551-7616. Available from: https://doi.org/10.1063/1.5011565

[11] SUGIARTO, S., LULUSI., L., MUTIAWATI, C., SALEH, S. M., A'YUNI Q., ISKANDAR, I. An exploration of factor affecting household's travel cost budget considering household life stages applying to urban bus ridership. Aceh International Journal of Science and Technology [online]. 2020, 9(1), p. 12-21. ISSN 2088-9860, eISSN 2503-2348. Available from: https://doi.org/10.13170/aijst.9.1.16405

[12] SUGIARTO, S., MIWA, T., MORIKAWA, T. Inclusion of latent constructs in utilitarian resource allocation model for analyzing revenue spending options in congestion charging policy. Transportation Research Part A: Policy and Practice [online]. 2017, 103, p. 36-53. ISSN 0965-8564. Available from: https://doi.org/10.1016/j.tra.2017.05.019

[13] AIGNER, D., KNOX LOVELL, C.A., SCHMIDT, P. Formulation and estimation of stochastic frontier production function models. Journal of Econometrics [online]. 1997, 6(1), p. 21-37. ISSN 0304-4076. Available from: https://doi.org/10.1016/0304-4076(77)90052-5

[14] BANARJEE, A., Y. X., PENYALA, M. R. Understanding travel time expenditures around the world: exploring the nation of a travel time frontier. Transportation [online]. 2007, 34, p. 51-65. ISSN 0049-4488, eISSN 1572-9435. Available from: https://doi.org/10.1007/s11116-006-0004-6

[15] SUSILO, O. Y., AVINERI, E. The impacts of household structure on the individual stochastic travel and out of home activity time budgets. Journal of Advanced Transportation [online]. 2013, 48(5) p. 454-470. ISSN 1042-7163, eISSN 1098-1071. Available from: https://doi.org/10.1002/atr.1234

[16] VOLOSIN, E. S., PAUL, S., CHRISTIAN, P. K., KONDURI, C. K., PENDYALA, M. R. Exploring the dynamics in travel time frontiers. Transportation Research Record: Journal of the Transportation Research Board [online]. 2013, 2382, p. 20-27. ISSN 0361-1981, eISSN 2169-4052. Available from: https://doi.org/10.3141/2382-03

[17] SALEH, S. M., SUGIARTO, S. Stochastic production frontier models to explore constraints on household travel expenditures considering household income classes. Aceh International Journal of Science and Technology [online]. 2016, 5(1), p. 9-17. ISSN 2088-9860, eISSN 2503-2348. Available from: https://doi.org/10.13170/aijst.5.1.3839

[18] SUGIARTO, S., MIWA, T., SATO, H., MORIKAWA, T. The tendency of public's attitudes to evaluate urban congestion charging policy in Asian megacity perspective: case a study in Jakarta, Indonesia. Case Studies on Transport Policy [online]. 2020, 8(1), p. 143-152. ISSN 2213-624X. Available from: https://doi.org/10.1016/j.cstp.2018.09.010

[19] SUGIARTO, S., SALEH, S. M. Investigating public perceptions and its implication toward Trans Koetardja policy considering latent motivation. IOP Conference Series: Materials Science and Engineering [online]. 2019, 523, 012036. ISSN 1757-8981, eISSN 1757-899X. Available from: https://doi.org/10.1088/1757-899X/523/1/012036

[20] TOSA, C., SATO, H., MORIKAWA, T., MIWA, T. Commuting behavior in emerging urban areas: findings of a revealedpreferences and stated-intentions survey in Cluj-Napoca, Romania. Journal of Transport Geography [online]. 2018, 68, p. 78-93. ISSN 0966-6923. Available from: https://doi.org/10.1016/j.jtrangeo.2018.02.011

[21] TOSA, C., MITREA, A., SATO, H., MORIKAWA, T., MIWA, T. Economic growth and urban metamorphosis: a quarter century of transformations within the metropolitan area of Bucharest. Journal of Transport and Land Use [online]. 2018, 11(1), p. 273-295. ISSN 1938-7849. Available from: https://doi.org/10.5198/jtlu.2018.1242 


\section{Abbreviation}

\begin{tabular}{ll}
\hline abbreviation & meaning/phrase \\
\hline HTS & Household Transport Survey \\
IDR & Indonesian Rupiah \\
IID & Identical and Independent Distributed \\
LL & Log-Likelihood \\
SFA & Stochastic Frontier Analysis \\
SFM & Stochastic Frontier Model \\
TCB & Travel Costs Budget \\
TCBF & Travel Costs Budget Frontier \\
\hline
\end{tabular}

